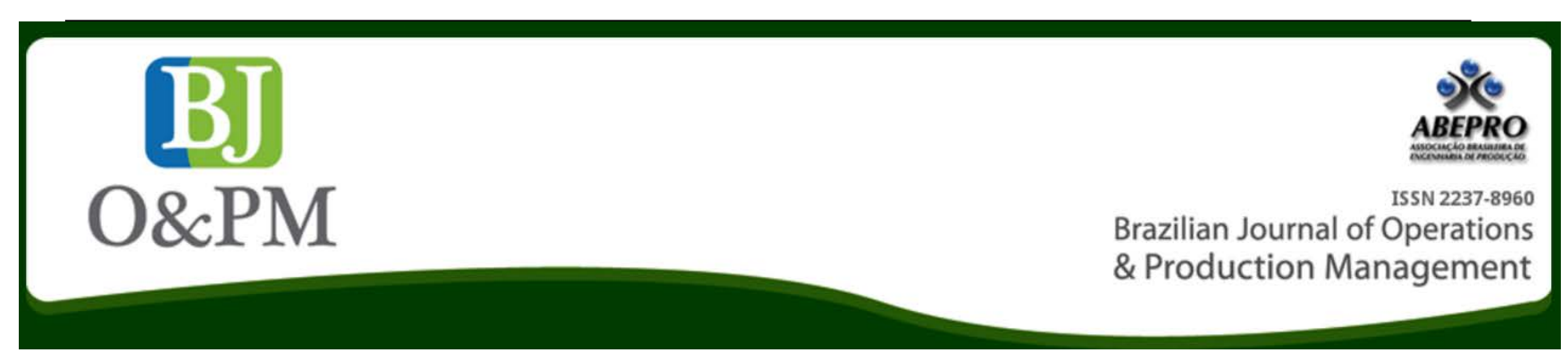

\title{
MODULAR CONSORTIUM (MC) AND INDUSTRIAL CONDOMINIUM (IC) IN BRAZIL'S AUTOMOTIVE INDUSTRY
}

\author{
Haroldo Lhou Hasegawaa; Délvio Venanzia; Orlando Roque da Silva ${ }^{b}$ \\ a University of Sorocaba (UNISO) - Sorocaba, SP, Brazil \\ ${ }^{b}$ Faculdades Metropolitadas Unidas (FMU) - São Paulo, SP, Brazil
}

\begin{abstract}
This paper aims to analyze the benefits of Modular Consortium (MC) and Industrial Condominium (IC) adopted by four auto makers located on Brazil, using exploratory case study conducted in 2013. The key element of success for modern companies or in other words, modern management is the alignment of operation strategy with production practice. It was concluded that although both of models have a positive impact of competitive priority like quick decision making in the production process, gains in stock level reduction and integration of the physical flow and information between the manufacturer and suppliers. On the other hand both of models have negative impact like loss of flexibility in case of a change in suppliers and logistics and problems that may arise as a result of modulists producing modules in other factories.
\end{abstract}

Keywords: Competitive Priorities, Modular Consortium, Industrial Condominium

\section{INTRODUCTION}

As a result of the increased competitiveness of the global automobile sector, industries and suppliers have been adopting new supply chain configurations aimed at greater integration and gains for the participants. Many of these new production configurations have been implemented in emerging countries, where new plants have been built. The emerging countries that are part of BRICS (Brazil, Russia, India, China and South Africa) are considered more attractive for installing new automobile factories due to the accelerated growth in the local automobile market and the low-cost production base.

In Brazil, the total amount of new investments near to US\$ 16 billion until 2016 and including the new factory of Audi, FCA (Fiat-Chrysler Automobiles), Toyota, Honda, Land-Rover and Chinese Manufacturers like as Cherry Motors and JAC Motors. They permitted establishing an installed base with an annual production capacity of 4.8 million automobiles at least (ANFAVEA, 2015).

According to Csizmazia (2014), the success of Toyota Production System (TPS), known as a Lean Manufacturing, induced to other automobile manufactures change the strategy for looking the way to combine standardization with an innovate production system using components or design are produced in worldwide scale. This process lead by Europe car manufacturers is called Modular Production System.

Among the innovative production configurations installed in Brazil, those that stand out are the new supply parks like the Modular Consortium (MC) and Industrial Condominium (IC). The characteristic of these models is the manufacturer's presence as director of the entire project. That means it will decide which products are supplied through the condominium, which companies will provide these products, where they are located in the condominium and how deliveries should be made. The production configuration called IC is where some direct suppliers, called "systemists", are chosen by the manufacturer to set up their installations in areas adjacent to the plant, projecting the location of systemizes at the point nearest system delivery on the assembly line.

These suppliers begin to deliver systems, sharing plant infrastructure costs with the manufacturer. These systems are complex sets of components that facilitate product delay and potential customization. This delivery is usually based on Just-in-Sequence (JIS - Just-in-time with sequenced deliveries) near the assembly line, but the assembly itself is done by the manufacturer. A difference in systemizes when compared to suppliers is that they participate in the 
elaboration and design of some systems. The difference between $\mathrm{MC}$ and IC is that with IC the addition of assemblies on the assembly line is done by the manufacturer's own employees, whereas with MC, the supplier's employees work at assembling systems on the assembly line. Another difference is that IC suppliers are installed on manufacturer land and around it, and they are responsible for the justin-sequence supply of systems. The MC partner company modules are set up inside the manufacturing plant and are responsible for producing the modules on the final assembly line.

With the emergence of these new configurations, there was a perspective that they would become dominant in the future of the global automobile industry. However, what has been observed is that these models have not been adopted at the originally projected speed. This leads to questions related to: 1) Condition of adoption of these models in emerging countries; 2) Expected gains from installation of the modular strategy; and 3) What is the competitive base of MC and IC configurations in relation to traditional production configurations. In the study, traditional production configurations are considered the supply chain configurations found in the automotive industry and that are strongly founded on mass production or lean production paradigms. This study uses the presupposition that IC and MC production configurations are an alternative to others in force. In this context, the objective of this study was to analyze the implications adopting Modular Consortium (MC) and Industrial Condominium (IC) models have on the manufacturer's competitive priorities, from an operations strategy perspective. The intention was to thus contribute towards a dynamic understanding of the adoption of these production models in the Brazilian and global automobile industry.

\section{SCIENTIFIC METHODOLOGY}

The new production configurations are present in two plants studied in this paper: General Motors (GM) in Gravataí, as an automobile production plant with the IC production configuration and Volkswagen (VW) Resende, with a truck production plant that uses the MC production configuration.
Two other manufacturing plants in the study are: GM in São Caetano do Sul (automobile producer) and Mercedes-Benz (MB) in São Bernardo do Campo (truck manufacturer), both using traditional production configurations. Table 1 shows the general characteristics of the manufacturing units participating in the case studies.

In this deductive research of an exploratory nature and qualitative approach, the case study research method was employed, adopting the comparison between pairs strategy for case studies. A pair of case studies was considered for each of the mentioned models (IC/MC and traditional production configuration). The direct observation and semi-structured interview techniques were used in data collection. Members of the auto manufacturer's strategic and tactical levels were interviewed in each case study. The interviews were recorded and later edited. The observation technique permitted crossing checking interview data and information.

Table 1. Characteristics of Studied Manufacturers

\begin{tabular}{|c|c|}
\hline Variables & Manufacturer Characteristics \\
\hline Plant & Volkswagem: VW (Rezende-Rio de Janeiro) \\
\hline Production Model & Modular Consortium (MC) \\
\hline Main Products & Trucks and Buses Chassis \\
\hline Installed Suppliers & 7 (seven) in modulus \\
\hline Plant & $\begin{array}{c}\text { General Motors: GM (Gravatai-Rio Grande } \\
\text { do Sul) }\end{array}$ \\
\hline Production Model & Industrial Condominium (IC) \\
\hline Products & Compact Automobiles \\
\hline Installed Suppliers & 17 (seventeen) Systemists \\
\hline Plant & $\begin{array}{c}\text { General Motors:GM (Sao Caetano do Sul- } \\
\text { Sao Paulo }\end{array}$ \\
\hline Production Model & Traditional/Conventional \\
\hline Products & Mid-Size Automobiles \\
\hline Suppliers & 85 (eighty five) \\
\hline Plant & $\begin{array}{c}\text { Mercedes Benz: MB (São Bernanrdo do } \\
\text { Campo-São Paulo) }\end{array}$ \\
\hline Production Model & Traditional/Conventional \\
\hline Products & Trucks and bus chassis \\
\hline Suppliers & 117 (one hundred seventeen) \\
\hline
\end{tabular}

Source: The authors own. 
Direct observation was used during the visit to company installations. Field research at the four manufacturers first verified the consistencies between each manufacturer's competitive priorities (CPs) and decision areas (DAs). For a more detailed analysis with study results from the four case studies, a matrix was elaborated listing all the competitive priorities and decision areas for each manufacturer, discussing the effects of decisions made at the DA compared to the CP level. The manufacturers' CPs were classified based on informer reports and on decisions made at the DA level. These CPs were divided into order winning and qualifying criteria, as shown in Table 2.

Table 2. Manufacturers' Competitive Priorities

\begin{tabular}{|c|c|c|}
\hline Manufacturer & $\begin{array}{c}\text { Order Winning } \\
\text { Criteria }\end{array}$ & Qualifying Criteria \\
\hline $\begin{array}{l}\text { VW (Rezende- } \\
\text { Rio de Janeiro) }\end{array}$ & $\begin{array}{l}\text { Const (C), } \\
\text { Flexibility (F) }\end{array}$ & $\begin{array}{l}\text { Reliability (Cf), Innovation } \\
\text { (I), Quality (Q), Speed (R) }\end{array}$ \\
\hline $\begin{array}{l}\text { GM (Gravatai- } \\
\text { Rio Grande do } \\
\text { Sul) }\end{array}$ & $\begin{array}{l}\text { Const (C), } \\
\text { Flexibility (F) }\end{array}$ & $\begin{array}{l}\text { Reliability (Cf), Innovation } \\
\text { (I), Quality (Q), Speed (R) }\end{array}$ \\
\hline $\begin{array}{c}\text { GM (São } \\
\text { Caetano do } \\
\text { Sul-São Paulo) }\end{array}$ & $\begin{array}{l}\text { Const (C), } \\
\text { Flexibility (F) }\end{array}$ & $\begin{array}{l}\text { Reliability (Cf), Innovation } \\
\text { (I), Quality (Q), Speed (R) }\end{array}$ \\
\hline $\begin{array}{c}\text { MB (São } \\
\text { Bernardo do } \\
\text { Campo São } \\
\text { Paulo) }\end{array}$ & $\begin{array}{c}\text { Const (C), Quality } \\
\text { (Q) }\end{array}$ & $\begin{array}{l}\text { Reliability (Cf), Innovation } \\
\text { (I), Flexibility (F), Speed (R) }\end{array}$ \\
\hline
\end{tabular}

Source: The authors own.

\section{LITERATURE REVIEW}

\subsection{Operations Strategy}

Several definitions of the Operations Strategy concept can be found in literature, each one focused on a specific aspect of operations management or a school of thought regarding strategy. According to Hayes et al., (2004, p. 51), [...] the operations strategy is a set of objectives, policies and self-imposed restrictions that together define how the organization intends to direct and develop all the resources invested in operations in order to better execute (and possibly redefine) its mission. Below, the elements that are part of operations strategy are explained: competitive priorities and analysis of structural and infrastructural decisions.

\subsection{Competitive Priorities and Decision Areas}

Competitive priorities are also called performance objectives and they are the master guidelines to position the manufacturer in the eyes of social groups with ties of interest in the organization. Competitive priorities act as competitive objectives selected to support a business strategy. The priorities dealt with in this article are: Cost, Reliability, Flexibility, Quality, Innovation, and Speed.

Decision areas refer to basic issues regarding the manufacturer's structure and infrastructure and are inserted in the operations strategy formulation strategy. Hayes. et al., (2004) presented an organized model that groups these decisions in categories, making it possible to identify and plan the functional strategy for manufacturing. The model introduces eleven decision categories that determine a manufacturing function's structure and capacity, as seen in Table 3.

Table 3. Production strategy decision categories

Structural Decisions

Capacity - quantity, type, time.

Supply and Vertical Integration - direction, extension, balance. Installations - size, location and specialization.

Information and Process Technology - degree of automation, interconnectivity, lead vs. follow.

\section{Infrastructural Systems and Policies}

Capital budget resource and systems allocation

Human resource systems - selection, skills, compensation, employee safety

Job Planning and Controlling- purchases, aggregate plan, planning, control or stock and/or wait time reserve

Quality systems - defect prevention, monitoring, intervention and elimination

Award measurement and systems - measurements, bonuses, promotion policy.

Product and process development systems - leader or follower, project team organization.

Organization - centralized vs. decentralized, which decisions to delegate, role of support groups.

Source: Hayes et al., (2004)

\subsection{Concept of Modularity}

Companies that operate in environments with fast product life cycles have incorporated modularization as a competitive strategy that helps respond to the market's fastest demands. Modularity is a product design concept where the final product is built from a number of product modules. The modules are assembled to configure a large number of final product variations. (Sanchez, 2002). Modularity is defined as a continuum that describes the degree to which a system's components can be separated, recombined and referenced, submitted to coupling voltage (power) between components

and the degree to which the rules of system architecture permit mixing and combining components. (Schilling, 2000). Modular production emphasizes development of the skill 
to select the necessary components and sub-assemblies before the project begins. In other words, modularization does not require much adjusting of the design between components and sub-assemblies in order to achieve product functions clients desire, and success comes from the skill to carefully select pre-designed components. (Fujimoto et Nobeoka, 2004). According to Mikkola (2006), modularity benefits include: quick product development process, increasing the scale of variations, promoting fast product technology, reducing the number of suppliers and reducing development and production costs. Holweg (2001) says companies with high levels of modularity in their products obtain greater cost reductions, since in the event of product returns, they can be easily disassembled.

The modularization strategy goes beyond the module's physical and functional dimensions that include an organizational and management system that connects module integrators and suppliers to reduce the cost of controlling tacit knowledge in the assembly process. Thus, modularization deals with a structured approach based on the complexity, technology and information flow, and where they are inserted in the companies. (Graziadio et Zilbovicius, 2003). More recently, we can observe that organizations increasingly adopt modular production as a strategic organizational arrangement to simultaneously use modular product platforms and modular process architectures as enablers of strategic flexibility (Krikke et al., 2004).

According to Fulginiti, Santos and Hansen (2015), Neto, Pires et Silva (2013), Kotabe et Mol (2004), the automobile industry in Brazil offers a favorable environment to examine antecedents and modularization strategy results in the project and in automobile production. In the USA, where unions are strong, it is difficult to practice this strategy because partners must deliver the modules or systems to the production line already ready, eliminating many of the operations that used to be carried out internally and leading to a possible reduction in jobs. An empirical analysis of the case studies is shown below from an operations strategy perspective.

\section{RESULTS AND DISCUSSION}

\subsection{Volkswagem (VW, Resende, RJ)}

Product architecture at this plant is modular, and VW only works with modules. The product is broken down into subsystems, which facilitates assembly, minimizes errors and relations between participants get stronger. Plant capacity is forty-eight thousand vehicles/year, with an average of two hundred twenty vehicles day. Vertical integration in a modular system is narrow since $\mathrm{MC}$ adopts vertical disintegration, with the partners working onsite at the company. There is a commitment by modulists as to the modules to be placed on the final assembly line, error-free, since they are paid only when the product is approved and accepted. VW's process technology has a very expressive degree of automation, with robots on the assembly line, cells and robotized islands. The allocation of resources in Resende is done according to a plan between the unit and headquarters, analyzing the truck market in Brazil and the competition. Since it is the only MC factory in the group, resources have been constantly applied by headquarters.

The HR system at VW is uniform in the MC. With several companies in the same locale, it would not be interesting from a management standpoint for each of the companies to create its own job and salary policy. Production Control and Planning at the MC is managed by VW and based on projected demand. With the passage of time, internal adjustments and the adaption of all the crippled vehicles (incomplete vehicles wait in an area adjacent to the line until the missing parts arrive at the $\mathrm{MC}$ ) has fallen off considerably, since the coordination of supply improves on a daily basis at VW. Internal logistics follows up on deliveries and missing components, but PCP is not integrated to external suppliers (second layer and above). Shared purchases, coordinated by $\mathrm{VW}$, rather than being made isolated, facilitate obtaining economies of scale and better payment and delivery prices and conditions.

VW uses the MTO (Make To Order) production system made to order, adding the customization of models entitled in the Tailor-Made MC, for the personalized service of clients and RSV (Request for Special Vehicles). The client can have a different product design and then engineering enters the process and verifies the feasibility of this customized product with module partners in terms of financial aspects and scale of production. The suppliers are minimal at the first layer (seven), delivering and assembling modules in the end of the line assembly process. The engine module supplier is the only case where a joint venture was formed, with this module being shared by two engine manufacturers. The first company is specialized in engines produced in large scale whereas the second is specialized in customized engine projects. The selection criteria for the suppliers were strict, based on competitive priorities, plus the supplier's organizational, managerial and financial aspects. This process lasted on year until seven modulists were chosen.

Stock management in the $\mathrm{MC}$ is done by logistic operators (internal and external) and by the modulist responsible for the module in final assembly. The modulists are responsible for the stock policy to be practiced. They are responsible for the material at VW and the modules will be integrated to the modulists. The quality system used in Resende is the group's global standard: Audit. It identifies problems in vehicles ready to be sold and follows the Volkswagen Group's global guidelines. The manufacturer has been achieving averages identical to the index established as a goal, or 1.7 
on a scale from 5 to 0 . The supplier must have a product and service quality system, thus eliminating the purchasing company's inspection work. VW uses managerial tools for incremental improvements in quality. The time cycle for solving problems is very short and the presence of modulists in the work site is a differential. The organizational design has a decentralized and horizontal structure, contributing towards agile communication. When there is a satisfactory flow of information, each manager has autonomy through the strategic objectives.

\subsection{General Motors (GM, Gravataí RS)}

GM (Gravataí) uses modular product architecture for manufacturing. The unit's capacity is at two hundred fifty thousand vehicles per year, and the site was chosen due to the following factors: proximity of suppliers, skilled labor and logistics (proximity to highways and ports). The IC production configuration used in this factory is a narrow vertical integration extension. Process technology in Gravataí uses a high level of automation, since there are many robots in island formation on the production line. The following equipment is used for movement: "dollies", or small tractors pulling a certain number of carts to take the modules to the exact site on the assembly line, AGVs (automated guided vehicles) and other movement equipment such as forklifts.

In terms of Information Technology, the following tools are used: Early Supplier Involvement (ESI), e-business and e-procurement, which seek greater integration and synchronism in activities. The company only has seventeen first tier suppliers inside the site. These suppliers were attested in: quality, since they are working with other manufacturers, financial situation, internal management, investment in product and process technology, since they are focused on continuous improvement and are more flexible to the market's continuous changes.

The Human Resources system considers awards for recognition and performance and it is adapted to current market standards. The company is geared towards constant internal and external training (60h/employee/year) and it conducts employee exchanges with other units outside the country for exchanging know-how. The planning and production control system (it uses MRP for materials planning) is linked to the ERP (Enterprise Resources Planning) system and controls production by means of monthly projections. Stocks are only maintained for the few imported items for supply safety reasons since the stocks of components that will shape systems are the responsibility of internal systemists. The factory's production system uses sequenced JIT (just-in-time in sequenced format) permitting the reduction of stock levels at the factory and manufacturing cost reductions. In IC, the modules are outsourced to partner companies, which were placed in strategic positions on the assembly line, following the sequence of modules to be assembled. The module components are manufactured by outsourced companies that are responsible for delivering these components to the point of use to be added to the modules. These modules are then delivered to the final assembly line by 3PL Logistics Operators to be added to the vehicles by manufacturer employees. The components that come from outside the complex are centralized in a cargo consolidation center by a logistics operator and transported to the factory.

At an IC unit, stock management follows the lean concept, with partners in control of stock levels. The production system facilitates quality management since the module suppliers must ensure module quality before it can be added to the product on the line. Systemist participation is required in product development from the beginning of the process (from the planning and validation to the manufacturing phases). Organizational structure is matrix-based with a president of the corporation in Brazil reporting to the GM president in the USA, but with full autonomy to define new investments and new market niches.

\subsection{General Motors (GM, SCS - SP)}

The SCS plant is considered a traditional production configuration, although flexible, because it assembles several types of vehicles in various platforms. Product architecture is integral and a large number of parts are distributed along the production line. The line operates with few modules and many separate parts.

Unit capacity is two hundred fifty thousand vehicles/ year. The site was chosen as a result of some factors like proximity to suppliers and favorable logistics (proximity to highways and ports).

The factory has a relatively broad degree of vertical integration and installations are divided into product and process. Process technology has received several financial contributions for the expansion and automation of processes, seeking greater productivity in the process. Nearly $\mathrm{R} \$ 500$ million were invested in the line plus another $\mathrm{R} \$ 100$ million for the Technological Center for research on new materials and investments in simulation software just to include the new Vectra. The process has Radio Frequency by Identification (RFID) technology on the production line, providing the process with greater speed and reliability.

The extension of vertical integration is relatively broad, beginning with some components (in some sub-assemblies) to the delivery of finished products to clients. The delivery of modules by exclusive suppliers to the unit was recently started. In this supply chain, ESI (supplier involvement in product design) tools are considered in some modules. This unit became the company's Technological Center and 
it receives new investments in new products as well as processes.

The Human Resources system moderately to aggressively considers awards for recognition and performance and it is adapted to current market standards. The company is geared towards constant internal and external training. The award system is based on the generation of ideas, but they take too long to be implemented. Production Control and Planning $(P C P)$ is connected to the central information system where there are modules for Production. Demand management is carried out and manufacturing orders are pulled through Kanban. Supply is provided by suppliers, some with JIT, and this practice has been the unit's priority, since it permits scheduling production without errors, without rework, with uniform, balanced and rhythmic load.

The MTS (Make to Stock) production system is used due to the internal and line layout. Kanban is used internally for visual control of production. There are eighty-five active suppliers and there are supplier-based reduction programs. The selection criteria for these suppliers are: quality certificates, since they are supplying for other manufacturers, financial situation, internal management, investment in product and process technology, focus on continuous improvement and innovations, and the fact they are more adapted to the market's continuous changes. In this traditional production configuration plant, suppliers are more distant, not permitting the manufacturer to work without stock. The unit's quality system is structured on ISO 9000 and ISO 14000, and uses QFD (Quality Function Deployment) tools. There are continuous quality certification programs for suppliers, especially lower level ones. Process and product development are very competitive, so it is linked to the Technological Center, facilitating development and future innovation in products and processes. The organizational structure is matricial, with autonomy to define new investments and market niches for operation.

\subsection{Mercedes-Benz (MB, SBC - SP)}

This is described as a traditional production configuration. Product architecture at the MB plant is integral. Factory production capacity is high. Vertical integration is broad since there is little outsourcing in relation to total components. The manufacturer began the learning process of some Toyota Production System (TPS) pillars. Installations are classified according to product and process, with the cell layout predominant. The choice of this layout is due to factory characteristics: standardized processing operations to achieve large volume flow, processing a large variety of requirements. Chain extension is characterized as ample, prioritizing cost and quality and demanding the supplier have control along the chain with regard to quality.
Process technology favors the use of flexibility in equipment to meet unusual demands. Human Resources is standard, without any reward system with regard to the innovation of ideas in the process. The Production Control and Planning system manages production line stocks and scheduling. Information is passed on to the suppliers. The MTS production system is used, thus stock accumulates in the production line. The supplier base is numerous and relations with suppliers are not strong. This makes quality management and reductions in delay, scrap and rework indexes more difficult. Implementation of the lean manufacturing concept was initiated and is still in its embryonic phase. The manufacturer has deficiencies in supplier management, since they are in such large numbers.

The manufacturer's quality system has been its focus for improvements, together with product engineering, which is the manufacturer's differential. The organization has a vertical hierarchical structure, characteristic of the manufacturer's culture, where hierarchies predominate in decision making. MB has one hundred and eighteen active suppliers and they are concentrated in the southeast. There are still some deficiencies in terms of integration between the manufacturer and its suppliers. Chart 4 summarizes the characteristics of the four manufacturers at the DA level.

\section{CONCLUSIONS}

Four case studies were carried out in this paper involving two alternative production configurations (IC/MC and traditional production configurations). The objective of this study was to analyze the implications adopting Modular Consortium (MC) and Industrial Condominium (IC) models have on the manufacturer's competitive priorities, from an operations strategy perspective. The paper studied the characteristics of each of these configurations at the production units and it conducted an analysis of the influence of these characteristics on competitive priorities. Table 4 shows the distribution of competitive priorities for each manufactures studied.

Studies at the VW (Rezende) and GM (Gravataí) units show that cost reductions and flexibility are the main competitive priorities (order winners), revealing that MC and IC are strongly founded on the search for cost reductions and improvements in flexibility. The focus on cost and flexibility is facilitated by the fact that: a) the modular configuration works with a very small supplier base; b) joint development of the modules with systemists/modulists; c) the assembly of modules on trucks (in the MC), which is dome by modulist employees, who will only be paid for services provided when the product reaches the end of the assembly line without pending quality issues and according to the production schedule; d) the physical proximity to modulists/systemists. Modules and systems in the condominium. 
Table 4. Manufacturers' competitive priorities

\begin{tabular}{|c|c|c|c|c|}
\hline Structural DA & VW, Rezende- RJ & GM, Gravataí-RS & GM, SCS-SP & MB, SBC-SP \\
\hline $\begin{array}{c}\text { Product } \\
\text { Architecture }\end{array}$ & Modular Product & Modular Product & Integral Product & Integral Product \\
\hline Capacity & $\begin{array}{c}\text { Quantity, type, equipment } \\
\text { speed and operators } \\
\text { capacity }\end{array}$ & $\begin{array}{c}\text { Quantity, type, equipment } \\
\text { speed and operators capacity }\end{array}$ & $\begin{array}{l}\text { Quantity, type, } \\
\text { equipment speed and } \\
\text { operators capacity }\end{array}$ & $\begin{array}{c}\text { Quantity, type, equipment } \\
\text { speed and operators } \\
\text { capacity }\end{array}$ \\
\hline Vertical Integration & $\begin{array}{l}\text { Deverticalized, but there } \\
\text { in Virtual Integration }\end{array}$ & $\begin{array}{l}\text { Not Integrated Vertically, } \\
\text { there is Virtual Integration }\end{array}$ & $\begin{array}{l}\text { Vertically Integrated } \\
\text { (Deverticalization has } \\
\text { begun) }\end{array}$ & Vertically Integrated \\
\hline Installations & $\begin{array}{c}\text { Focus on Products and } \\
\text { Process }\end{array}$ & $\begin{array}{c}\text { Focus on Products and } \\
\text { Process }\end{array}$ & $\begin{array}{c}\text { Focus on Products and } \\
\text { Process }\end{array}$ & $\begin{array}{c}\text { Focus on Products and } \\
\text { Process }\end{array}$ \\
\hline Process Technology & $\begin{array}{c}\text { Equipment, degree } \\
\text { of Automation Level, } \\
\text { Achieve Performance } \\
\text { Goals Under Operating } \\
\text { Conditions }\end{array}$ & $\begin{array}{l}\text { Equipment, degree of } \\
\text { Automation Level, Achieve } \\
\text { Performance Goals Under } \\
\text { Operating Conditions }\end{array}$ & $\begin{array}{l}\text { Degree of Automation } \\
\text { Level, Integration and } \\
\text { Technological Capacity }\end{array}$ & $\begin{array}{l}\text { Equipment, degree of } \\
\text { Automation Level, Achieve } \\
\text { Performance Goals Under } \\
\text { Operating Conditions }\end{array}$ \\
\hline Chain Extension & Narrow & Narrow & Relatively Broad & Relatively Broad \\
\hline Resourse Allocation & $\begin{array}{l}\text { Expantion and Alteration } \\
\text { of Production line Aimed } \\
\text { at satisfying the Market }\end{array}$ & $\begin{array}{l}\text { Expantion and Alteration } \\
\text { of Production line Aimed at } \\
\text { satisfying the Market }\end{array}$ & $\begin{array}{l}\text { Expantion and } \\
\text { Alteration of } \\
\text { Production line Aimed } \\
\text { at satisfying the Market }\end{array}$ & $\begin{array}{l}\text { Expantion and Alteration } \\
\text { of Production line Aimed at } \\
\text { satisfying the Market }\end{array}$ \\
\hline HR Systems & $\begin{array}{l}\text { Resources Policies } \\
\text { Planned per } \\
\text { Empowerment }\end{array}$ & $\begin{array}{c}\text { Performance Policies } \\
\text { and Recognition and } \\
\text { Development }\end{array}$ & $\begin{array}{c}\text { Performance Policies } \\
\text { and Recognition and } \\
\text { Development }\end{array}$ & Common HR Policy \\
\hline $\begin{array}{l}\text { Planning and } \\
\text { Control }\end{array}$ & $\begin{array}{c}\text { Supply Policies, } \\
\text { Centralization, } \\
\text { Programing, Stock Control }\end{array}$ & $\begin{array}{c}\text { Supply Policies, } \\
\text { Centralization, Programing, } \\
\text { Stock Control }\end{array}$ & $\begin{array}{l}\text { Supply Policies, } \\
\text { Centralization, } \\
\text { Programing, Stock } \\
\text { Control }\end{array}$ & $\begin{array}{c}\text { Supply Policies, } \\
\text { Centralization, Programing, } \\
\text { Stock Control }\end{array}$ \\
\hline Production System & MTO (as Requested) & $\begin{array}{l}\text { Use of Pull System (JIT/ } \\
\text { Kanban) }\end{array}$ & $\begin{array}{l}\text { Use of Pull System (JIT/ } \\
\text { Kanban) }\end{array}$ & MTS (Make to Stock) \\
\hline Supplies & $\begin{array}{l}\text { Broad Relation, Make the } \\
\text { Final Assembly Partners }\end{array}$ & Lean and Internal Partners & External Suppliers & $\begin{array}{l}\text { External, Tradicional } \\
\text { Supplies }\end{array}$ \\
\hline Selection Criteria & $\begin{array}{l}\text { Investment, Product/ } \\
\text { Process Technology, CP }\end{array}$ & $\begin{array}{l}\text { Investment, Product/Process } \\
\text { Technology, CP }\end{array}$ & $\begin{array}{l}\text { Investment, Product/ } \\
\text { Process Technology, CP }\end{array}$ & $\begin{array}{c}\text { Financial Condition, } \\
\text { Technology Competitive } \\
\text { Priorities }\end{array}$ \\
\hline Stock Management & $\begin{array}{l}\text { Partner Stock, Internal } \\
\text { Logistics Control }\end{array}$ & $\begin{array}{c}\text { Supplies, Storage and } \\
\text { Material Movement } \\
\text { Technology }\end{array}$ & $\begin{array}{l}\text { Supplies, Storage, } \\
\text { Control System } \\
\text { Technology }\end{array}$ & $\begin{array}{l}\text { Safety Stock for Some } \\
\text { Components }\end{array}$ \\
\hline Quality System & $\begin{array}{l}\text { Prevention, Monitoring } \\
\text { and Audit }\end{array}$ & $\begin{array}{l}\text { Prevention, Monitoring Client } \\
\text { Needs and Expectations as to } \\
\text { Manufactured Products }\end{array}$ & $\begin{array}{l}\text { Prevention, Monitoring } \\
\text { Client Needs and } \\
\text { Expectations as to } \\
\text { Manufactured Products }\end{array}$ & $\begin{array}{l}\text { Monitoring, Follows ISO } \\
\text { and applies Quality Tools in } \\
\text { the Process }\end{array}$ \\
\hline $\begin{array}{l}\text { Products } \\
\text { and Process } \\
\text { Development }\end{array}$ & In Some Modules & $\begin{array}{l}\text { Provides Competitive } \\
\text { Differential by Promoting } \\
\text { New Process and Products }\end{array}$ & $\begin{array}{l}\text { Provides Competitive } \\
\text { Differential by } \\
\text { Promoting New Process } \\
\text { and Products }\end{array}$ & $\begin{array}{l}\text { Provides Competitive } \\
\text { Differential by Promoting } \\
\text { New Process and Products }\end{array}$ \\
\hline Organization & $\begin{array}{c}\text { Horizontal Structure and } \\
\text { Decentralized }\end{array}$ & $\begin{array}{l}\text { Matriacial Structure with } \\
\text { Empowement Leadership } \\
\text { Style }\end{array}$ & $\begin{array}{l}\text { Matriacial Structure } \\
\text { with Empowement } \\
\text { Leadership Style }\end{array}$ & $\begin{array}{l}\text { Centralized and Vertical } \\
\text { Structure }\end{array}$ \\
\hline
\end{tabular}




\section{REFERENCES}

ANFAVEA-Association of National Automotor Veichle Manufacturer (2015), "anuario" April 2015, Avaiable: http:// www.anfavea.com.br. access: 29 April 2015.

Csizmazia, R. A. (2014), "Reconfiguration of Supply Chain at Volkswagen Group to Develop Global", International Journal of Academic Research in Business and Social Sciences, December 2014, Vol.4, No12, pp.294-305.

Fujimoto, T. and Nobeoka, K. (2004), "In which industries does Japan excel? The compatibility between architecture and organizational capability" RIETI Discussion Paper Series, August 2004, No.04- J-040, Available: http://www.rieti. go.jp/en/publications/summary/04080003.html. Access:14 November 2014.

Fuljiniti B.C., Santos, J.L. and Hanses, P,B. (2015), "Facilitating Factors of Supply Chain Management: A Study in the Automotive Industry in Brazil", Business and Management Review, February 2015, Vol 4, No 1, pp. 290300.

Graziadio, T. and Zilbovicius, M. (2003), "Knowledge transfer through the supply system: does modularity make it easier?", International Journal of Automotive Technology and Management, Vol. 3 No. 1-2, pp. 47-60.

Hayes, R., Pisano, G., Upton, D. and Wheelwright, S. (2004), Operations, strategy and technology: pursuing the competitive edge, John Wiley \& Sons, Hoboken.

Holweg, M. and Pil, F.K. (2001), "Successful Build-to-Order Strategies start with the Customer", MIT Sloan Management Review, Fall issue, Vol. 43 No. 1, pp. 74-83.

Krikke, H., Le Blanc, I. and Van de Velde, S. (2004), "Product modularity and the design of closed loop supply chains", California Management Review, Vol. 46 No. 2, pp. 23-39.

Kotabe, M. and Mol, M.J. (2004), "A New paradigm on outsourcing and the performance of the firm", in Trick, M. A. (ed.) Global corporate evolution: looking inward or looking outward?, Carnegie Mellon University Press, Pittsburgh, pp. 331-339.

Mikkola, J.H. (2006), "Product development and management association capturing the degree of modularity embedded in product architectures", Journal of Product Innovation Management, Vol. 23, pp. 128-146.

Neto, M.S., Pires, S.R.I. and Silva, E.M. (2013), “Modularity and Relational Mechanisms of Governance: An Analysis of Modular Consortium and Industrial Condominium", Journal of Operations and Supply Chain Management, January-June 2013, Vol. 6 No 1, pp. 74-90.
Sanchez, R. (2002), "Using modularity to manage the interactions of technical and industrial design", Design Management Journal Academic Review, Vol. 2 No. 1, pp. 8-19.

Schilling, M.A. (2000), "Toward a general modular systems theory and its application to interfirm product modularity", Academy of Management Review, Vol. 25 No. 2, pp. 312334. 